\title{
ASPECTE JURIDICE PRIVIND SĂNĂTATEA PUBLICĂ ÎN CONTEXTUL ISTORIC AL MARILOR EPIDEMII
}

„Mai înainte ca să vorbeşti, învață, şi mai înainte de boală te îngrijeşte. Mai înainte de judecată ispiteşte-te pe tine, şi în ceasul judecății vei afla milă. Mai înainte de boală smerește-te, şi în vremea păcatelor arată întoarcere.” Cartea înțelepciunii lui Isus, fiul lui Sirah (Ecclesiasticul) 18:19 - 21

Rezumat: $\mathrm{Cu}$ toate că noțiunea de sănătate publică este una modernă şi îț̦elegerea științifică a bolilor infecţioase și a transmiterii lor are o vârstă de aproximativ 200 de ani, chiar şi societățile antice şi medievale reacţionau într-o manieră organizată în fața marilor epidemii și a pericolului pe care acestea îl prezentau pentru ordinea publică și pentru existența lor. În ciuda faptului că sursele bolilor contagioase erau, adesea, vag sau greșit înțelese, unele dintre măsurile pe care aceste societăți au început să le ia (carantina, cordonul sanitar, izolarea bolnavilor, dezinfectarea obiectelor) s-au dovedit eficiente și au fost îmbunătățite continuu de-a lungul secolelor.

Acest studiu încearcă să prezinte, pe baza metodei istorice, unele dintre cele mai importante măsuri normative non-medicale din istoria epidemiilor, măsuri care au supraviețuit până în ziua de azi. Având în vedere natura juridică a acestui studiu, nu vom discuta aspectele medicale ale sănătății publice pe perioada pandemiilor, precum vaccinarea, tratamentul, diagnosticul ori îngrijirea medicală. Studiul se va

* Lector univ. dr., Departamentul de Drept Privat, Facultatea de Drept a Universității Babeș-Bolyai/; avocat, Baroul Cluj, contact: marius.floare@law.ubbcluj.ro.

\section{$\mathbf{2 8 6}$}


axa în principal pe Europa, deși unele referințe vor fi făcute, în trecere și la America de Nord. publică.

Cuvinte cheie: carantină, cordon sanitar, epidemie, pandemie, sănătate

\title{
LEGAL ISSUES REGARDING PUBLIC HEALTH \\ IN THE CONTEXT OF THE GREAT EPIDEMICS
}

\begin{abstract}
Although the concept of public health is a modern one and the scientific understanding of infectious diseases and their transmissibility is less than 200 years old, even ancient and medieval societies reacted in an organized manner to the great epidemics and the threat they posed to public order and their very existence. In spite of the fact that the sources of contagious diseases were often vaguely or wrongly understood, some of the measures that these older societies began to take (the quarantine, cordon sanitaire, isolating the sick, disinfecting objects) proved effective and have been continuously perfected along the centuries.

This study will attempt to discuss, using the historical method, some of the most important normative non-medical interventions in the history of epidemics that have survived to this day. Due to the legal nature of this study, we will not discuss the medical aspects of public health during pandemics, like vaccination, treatment, diagnosis or medical care. The focus of this study will be decisively European, although some passing references will be made to North America.
\end{abstract}

Keywords: quarantine, cordon sanitaire, epidemic, pandemic, public health 


\section{Cuprins}

I. Apariția unor măsuri de sănătate publică în contextul epidemiilor ......... 289

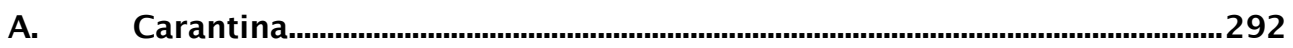

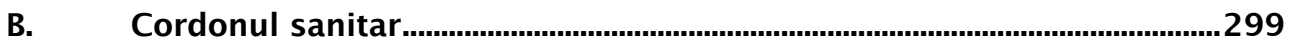



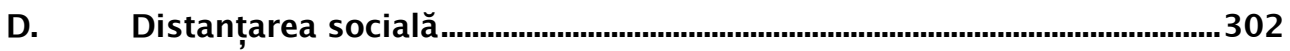

II. Cooperarea internațională în domeniul sănătății publice ....................... 303

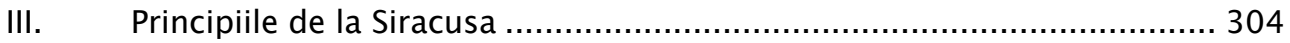

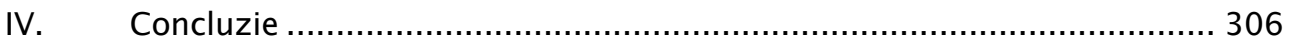

În aceste cumplite vremuri ale anului 2020, anul celei mai mari pandemii din ultima sută de ani, nu este lipsit de importanță să ne amintim că nu este nimic cu adevărat nou sub soare, că omenirea a trecut în lunga sa existență prin episoade similare, chiar dacă agentul patogen nu a fost unul identic. Efectele sociale ale pandemiilor, „distilate” în norme juridice adoptate de-a lungul timpului, reflectă încercările tuturor societăților umane de a controla şi combate epidemiile inter alia și prin mijloace de intervenție normativă non-medicală. În acest studiu, ocazionat de volumul omagial dedicat domnului profesor universitar doctor Vladimir Hanga, reputat specialist, printre altele, și în istoria dreptului, vom încerca, folosind metoda istorică, să identificăm aspecte comune ale reacției societăţilor prin mijloace non-medicale la provocările de sănătate publică generate de marile epidemii sau pandemii.

Noțiunea contemporană de politică de sănătate publică se referă la toate deciziile, planurile şi acțiunile care sunt întreprinse pentru a atinge scopuri specifice privind sănătatea într-o societate. O politică de sănătate publică ideală conturează prioritățile și rolurile diverselor grupuri sociale, încearcă să construiască consensul și să informeze populația. Chiar dacă 
aceste concepte sunt cât se poate de moderne ${ }^{1}$ și nu erau înțelese ca atare în epocile mai vechi, chiar și societățile premoderne, din antichitate și Evul Mediu, au urmat intuitiv anumite „politici de sănătate publică” când s-au văzut confruntate cu amenințarea existențială a unei mari epidemii.

În acest studiu vom încerca să identificăm, prin câteva jaloane semnificative, elemente normative ale acestor proto-politici de sănătate publică, care au apărut în contextul marilor epidemii din spaţiul european și au supraviețuit până în ziua de azi. Studiul nostru nu va acoperi aspectele medicale ale intervențiilor de sănătate publică (vaccinarea, tratamentele, diagnosticarea, îngrijirea bolnavilor) și se va concentra în principal pe spațiul european.

\section{Apariția unor măsuri de sănătate publică în contextul epidemiilor}

Înainte de secolul al XX-lea, boala epidemică ce a născut cele mai intense preocupări ale societăților din Europa a fost ciuma, care a lovit în valuri de-a lungul secolelor, cu diferite tulpini, în care predominau varianta bubonică sau cea pulmonară.

Prima pandemie de ciumă, ciuma lui Iustinian, care a debutat la mijlocul secolului al VI-lea d.Ch. și a durat aproximativ până în anii 750-755 d. Ch. ${ }^{2}$, a ucis aproximativ 40\% din populația capitalei Constantinopole,

\footnotetext{
${ }^{1}$ În acest sens a se vedea N.E. Kass, An Ethics Framework for Public Health, American Journal of Public Health, vol. 91, nr. 11/2001, p. 1776.

${ }^{2}$ A se vedea în acest sens K. Little (editor), Plague and the End of Antiquity - The Pandemic of 541-750, Cambridge University Press, Cambridge - New York, 2007; F. M. Snowden, 
generând primele măsuri cu iz de politici de sănătate publică: plata din fonduri publice a groparilor care să îngroape bolnavii decedați și a unor bărci care să arunce cadavrele infestate în mare, dar și persecutarea unor categorii sociale considerate responsabile de epidemie (evreii, samaritenii, păgânii, ereticii, homosexualii etc.) cărora le-a fost sever limitată libertatea de mișcare înspre capitală. ${ }^{3}$

A doua pandemie de ciumă4, din secolele al XIV-lea - al XIX-lea, caracterizată printr-o serie de valuri epidemice la diferite intervale de timp, este cea care a dat naștere unor instituții de sănătate publică5 în primul rând în orașele-state italiene (Veneția, Genova, Milano și Florența) care s-au izbit printre primele din Europa de grozăviile pandemiei. ${ }^{6}$

Oraşele italiene sunt cele care au ,inventat” comisarii sau magistrații sanitari, cu depline puteri legislative, judiciare şi executive legate de sănătatea publică, în baza unor reglementări speciale privind ciuma, funcții care aveau inițial un caracter temporar7, dar au devenit instituții permanente din secolul al XVI-lea, sub denumirea de „comitete sanitare”, compuse din notabilități locale, în arsenalul lor apărând instrumente validate ulterior de istorie cum

Epidemics and Society - From the Black Death to the Present, Yale University Press, New Haven and London, 2019, pp. 34-35.

3 K. Drews, A Brief History of Quarantine, Virginia Tech Undergraduate Historical Review, vol. 2, 2013, pp. 63-64.

4 Pentru periodizarea celor trei mari pandemii de ciumă a se vedea F.M. Snowden, op. cit., pp. 33-39.

5 A. Leca, A. Lunel, S. Sanchez, Histoire du Droit de la Santé, Les Études Hospitalières Édition, Bordeaux, 2014, p. 121.

${ }^{6}$ F.M. Snowden, op. cit., p. 69.

7 D. Porter, Health, Civilization and the State - A history of public health from ancient to modern times, Routledge, London and New York, p. 35. 
sunt carantina maritimă și cea terestră sau cordonul sanitar. ${ }^{8}$ Principiul străvechi care guverna aceste funcții extraordinare, principiu care în pandemia actuală pare uitat de unii oameni, era că sănătatea poporului este legea supremă (salus populi suprema lex esto). ${ }^{9}$

Pe lângă instrumentele juridice care au fost ulterior validate de istorie, acele politici incipiente de sănătate publică ale Evului Mediu și epocii postmedievale au dat naștere și unor măsuri reprobabile, care nu își mai au locul într-o societate civilizată: prigonirea și expulzarea unor persoane sau populații, purificarea etnică sau religioasă, pedepsirea neconformismului social etc.

Epoca modernă și contemporană, pe lângă utilizarea în continuare a măsurilor de sănătate publică legate de epidemii consacrate în secolele anterioare, a dezvoltat termenul-umbrelă de „distanțare socială” sub care au fost reunite măsuri mai vechi (carantina, izolarea bolnavilor, cordonul sanitar) cu măsuri mai noi (închiderea școlilor și a instituţiile publice, interzicerea evenimentelor care implicau prezența unui număr mare de persoane, recomandarea sau impunerea telemuncii etc.). ${ }^{10}$

Fundamentul etic al sănătății publice este utilitarismul, astfel că evitarea unor boli catastrofale sau diminuarea suferinței populației pot justifica încălcarea unor drepturi ale indivizilor prin intermediul unor măsuri asemeni carantinei, rechizițiilor sau vaccinării obligatorii. ${ }^{11}$ Măsurile de

\footnotetext{
${ }^{8}$ F.M. Snowden, op. cit., pp. 69-73; D. Porter, op. cit., p. 37.

9 F.M. Snowden, op. cit., pp. 69-73; principiul citat se regăsește în Cicero, De Legibus, cartea a III-a, partea a III-a, secțiunea a VIII-a, fiind frecvent folosit în lucrările de știință politică din epoca modernă.

10 M.A. Rothstein, From SARS to Ebola - Legal and Ethical Considerations for Modern Quarantine, Indiana Health Law Review, vol. 12, nr. 1/2015, pp. 234-235.

${ }^{11}$ Ibidem, p. 249.
} 
sănătate publică trebuie însă să fie într-adevăr necesare, să afecteze cât de puțin posibil libertatea indivizilor și să ofere garanția unui proces echitabil. ${ }^{12}$

Conflictul inerent între utilitarism și libertatea individuală trebuie rezolvat apelând la cinci criterii care arată dacă promovarea sănătății publice justifică încălcarea unor libertăţi ale individului: eficacitatea, proporţionalitatea, necesitatea, minima încălcare a drepturilor și justificarea publică. ${ }^{13}$

\section{A. Carantina}

Dintre măsurile de sănătate publică ce au fost consacrate în epoca medievală, cea care a dăinuit cu deosebit succes până în zilele noastre este carantina. Unii autori contemporani fac distincția riguroasă între veritabila carantină, care presupune înțelegerea unor concepte științifice cum este cel de perioadă de incubație sau noțiunea de germeni, și izolarea bolnavilor, care are o tradiție multimilenară ${ }^{14}$ și se baza frecvent pe teorii devenite astăzi desuete despre boală și bolnav.

Definiția contemporană a carantinei înseamnă restricţionarea mișcării persoanelor asimptomatice, cu posibilă expunere la o boală infecțioasă, în perioada de posibilă contagiozitate, pentru a preveni transmiterea bolii. ${ }^{15}$ Spre deosebire de aceasta, înțelesul modern al izolării este acela al separării persoanelor confirmate ca fiind infectate, pe perioada

12 Ibidem.

13 M.A. Rothstein, op. cit., pp. 249-250; J.F. Childress et al, Public Health Ethics: Mapping the Terrain, Journal of Law, Medicine \& Ethics, vol. 30, 2002, p. 173.

14 K. Drews, op. cit., p. 59.

15 L.O. Gostin, Public Health Law - Power, Duty, Restraint, University of California Press, Berkeley - Los Angeles London, 2008, p. 429; M. A. Rothstein, op. cit., p. 227. 
în care sunt contagioase, pentru a preveni transmiterea bolii. ${ }^{16}$ În acest studiu vom folosi noțiunea de carantină în sensul său larg, de restricționare a mișcării bunurilor și persoanelor, pe pământ sau pe mare, din cauza unei boli contagioase. ${ }^{17}$

Conceptul de izolare a persoanelor potențial bolnave o anumită perioadă de timp, pentru a da ocazia bolii suspectate să se manifeste în mod vizibil, se regăseşte şi în Vechiul testament, în capitolul 13 al Leviticului (cartea a treia a lui Moise), datând aproximativ din secolul al VII-lea î.Ch., unde se vorbește de cercetarea de către cleric a suspecților de lepră şi izolarea lor inițială câte şapte zile, cu posibilitate de prelungire cu încă şapte zile, pentru a decela dacă este vorba de leziuni cutanate cauzate de boala infecțioasă sau de simple bube. ${ }^{18}$ Şi în cartea următoare din Vechiul testament, Numerii, se arată la capitolul 5 că este obligatorie scoaterea din tabăra fiilor lui Israel a tuturor celor cu diverse semne de boală. ${ }^{19}$

Şi în lumea islamică timpurie se vorbea de izolarea bolnavilor contagioşi încă din secolul al VII-lea d.Ch., spitale fiind construite de primii califi încă din secolul al VIII-lea d.Ch.

\section{${ }^{16}$ Ibidem.}

17 E. Tognotti, Lessons from the History of Quarantine, from Plague to Influenza A, Emerging Infectious Diseases, vol. 19, nr. 2/2013, p. 254.

18 Leviticul 13:4-6 „Iar dacă pata de pe piele, deşi este albă, dar nu este şi adâncită în pielea lui, şi perii de pe ea nu s-au făcut albi, ci sunt negri, să închidă preotul pe cel cu rana şapte zile./În ziua a şaptea să vadă preotul rana: dacă rana a rămas ca înainte şi nu s-a întins rana pe piele, preotul să-l închidă alte şapte zile./În ziua a şaptea îl va cerceta preotul din nou şi dacă rana va fi slăbită şi nu se va fi întins rana pe piele, preotul să-l declare curat. Aceasta este o bubă şi cel ce o are să-şi spele hainele sale şi va fi curat.”.

19 Numerii 5:2-3 „Porunceşte fiilor lui Israel să scoată din tabără pe toți leproşii, pe toți cei ce au scurgere şi pe toți cei întinați prin atingere de mort./De la bărbat până la femeie să-i scoateți şi să-i trimiteți afară din tabără, ca să nu pângărească taberele lor, în mijlocul cărora locuiesc Eu". 
Conceptul modern de carantină se pare că își are însă originea în trentina apărută în colonia venețiană din orașul-port Ragusa (actualul Dubrovnik) din Croația, în cursul celei de-a doua marii pandemii de ciumă, care a început să străbată Europa, începând din sudul continentului, din 1347, ucigând aproximativ 30\% din populația continentuluii ${ }^{20}$. După o primă epidemie de ciumă în respectivul oraș, medicul-șef Iacob de Padova al oraşului Ragusa a recomandat înființarea unor localuri în afara zidurilor oraşului, unde să fie tratați localnicii bolnavi și străinii care veniseră în căutarea unui tratament, dar aceste simple recomandări nu au fost eficiente în practică. ${ }^{21}$ Marele Consiliu al oraşului Ragusa a stabilit în anul 1377 izolarea obligatorie, timp de 30 de zile, pe insule situate în afara zidurilor oraşului, a cetățenilor și vizitatorilor care veneau în oraș din zone unde ciuma era endemică, fiindu-le interzis localnicilor, cu excepția celor anume desemnați de Consiliu, să viziteze sau să aducă alimente celor aflaţi în izolare, sub sancțiunea de a rămâne şi ei 30 de zile în izolare. ${ }^{22}$

Alți autori²3 creditează chiar metropola venețiană cu codificarea în 1348 a măsurii închiderii portului în fața navelor suspecte, măsură pe care și alte oraşe italiene începuseră să o practice $a d$ hoc din 1347, precum și a izolării sistematice timp de treizeci de zile a călătorilor și a navelor chiar în port, cei din Ragusa având doar meritul de a fi înființat primii localurile de carantinare pe insulele învecinate.

\footnotetext{
20 P.S. Sehdev, The Origin of Quarantine, Clinical Infectious Diseases, vol. 35, nr. 9/2002, p. 1072.

${ }^{21}$ Ibidem.

${ }^{22}$ Ibidem.

23 D. Porter, op. cit., p. 33.
} 
Exemplul celor din Ragusa a fost urmat în secolul următor de Marsilia (1383), Veneția (1403), Mallorca (1471)24, Pisa și Genova, perioada de izolare de 30 de zile (trentino) fiind extinsă la 40 de zile (quarantino), explicaţiile acestei modificări variind de la cele empirice (perioada inițială de 30 de zile era insuficientă pentru a preveni răspândirea bolii, teoria antică hipocratică a „perioadei critice” de 40 de zile pentru distincția între o boală cronică și una acută) la cele religioase (posturile creștine mari sunt de 40 de zile, având un rol de purificare spirituală; o serie de evenimente din Biblie durează 40 de zile) ${ }^{25}$ sau explicații bazate pe teoria eronată a „miasmelor” producătoare de boală, care ar avea nevoie de un astfel de interval de timp pentru a se disipa ${ }^{26}$.

Pe lângă carantina maritimă a navelor care soseau în port, orașele italiene au utilizat și o așa-zisă „carantină reactivă”, prin care erau izolați și localnicii bolnavi şi familiile lor în propriile case, frecvent sub pază, pentru a nu răspândi boala în comunitate, în Milano ajungându-se până la zidirea uşilor caselor celor bolnavi. ${ }^{27}$

Această carantină de 40 de zile s-a încetățenit atât de bine încât a fost utilizată încă cel puțin 300 de ani în orașele-porturi italiene și din restul Europei, cu mici variațiuni locale în funcție de locul de proveniență al persoanelor potențial infectate, dovedindu-se în linii mari eficientă împotriva ciumei bubonice, ${ }^{28}$ care se estimează astăzi că avea o durată de 37 de zile de la infectare până la deces.

\footnotetext{
24 D. Porter, op. cit., p. 33.

25 P.S. Sehdev, op. cit., p. 1072; K. Drews, op. cit., pp. 66-67; J.P. Byrne (editor), Encyclopedia of Pestilence, Pandemics, and Plagues, Greenwod Press, Westport, Connecticut and London, 2008, p. 483.

${ }^{26}$ E. Tognotti, op. cit., p. 255; D. Porter, op. cit., pp. 33-34.

27 K. Drews, op. cit., p. 67; J.P. Byrne (editor), op. cit., p. 483.

${ }^{28}$ K. Drews, op. cit., pp. 67-68.
} 
Deși începuturile sale sunt intrinsec legate de a doua mare pandemie de ciumă bubonică, instrumentul carantinei a început să fie utilizat și în cazul altor epidemii, în America de Nord fiind folosită inițial în 1647 de colonia din golful Massachusetts pentru navale provenite din Indiile de Vest pentru a preveni ciuma ${ }^{29}$ dar, încă de la sfârșitul secolului al XVII-lea, era utilizată pentru a controla epidemiile de febră galbenă ce izbucniseră la Boston și New York $^{30}$, mai târziu orașul american Philadelphia înființând, în anul 1799, o stație de carantină pe râul Delaware, ca reacție la o epidemie devastatoare de febră galbenă din anul 1793, acolo fiind triați timp de aproape un secol pasagerii, navele și încărcătura care soseau în portul Philadelphia. ${ }^{31}$

Autoritățile laice din orașele-state italiene erau permanent preocupate de ordinea publică în contextul epidemiilor de ciumă, epidemia riscând să provoace dezordine și pulverizarea legăturilor sociale. Sănătatea publică era o preocupare subsecventă, doar în măsura în care risca să fie afectată ordinea socială existentă. ${ }^{22}$ Intervenţiile tot mai ferme pentru combaterea epidemiilor afectau însă interesele unora dintre cetățenii de vază, astfel încât tot mai puternicele autorități sanitare laice au făcut o serie de concesii în vederea păstrării păcii sociale, în faţa riscului ca epidemia să ruineze economic o comunitate: au acceptat fumigarea anumitor mărfuri ca mătasea sau lâna în loc de distrugerea lor, au plătit uneori compensații comercianților și muncitorilor pentru pierderile suferite ca urmare a măsurilor luate. 33

\footnotetext{
${ }^{29}$ M.A. Rothstein, op. cit., p. 230.

${ }^{30}$ Ibidem; E. Tognotti, op. cit., p. 255.

${ }^{31}$ K. Drews, op. cit., p. 69.

$3^{2}$ D. Porter, op. cit., pp. 35-36.

33 D. Porter, op. cit., pp. 36-38.
} 
În Europa, reglementările privind carantina legată de ciumă au fost permanent perfecționate şi extinse până în secolul al XVIII-lea, când au avut loc ultimele mari epidemii ale acestei boli, dar acelaşi instrument a ajuns să fie folosit pentru epidemiile mediteraneene de febră galbenă din secolul al XVIII-lea sau pentru epidemiile de holeră ce au urmat în secolul al XIX-lea. ${ }^{34}$ Carantina, care se dovedise eficientă împotriva ciumei, deşi mecanismul de transmitere al bolii fusese greșit înțeles până la sfârșitul secolului al XIX-lea, nu a mai avut aceeaşi eficiență împotriva noilor provocări ale febrei galbene (transmisă de țânțari) sau holerei (transmisă pe cale digestivă, frecvent prin apă contaminată) și venea în conflict cu ideile revoluționare privind libertatea și drepturile cetățenilor, epidemiile fiind utilizate frecvent ca un prilej de întărire a puterilor statului și ale poliției, de prigonire a opoziției sau a categoriilor sociale marginalizate. 35

Începând cu mijlocul secolului al XIX-lea, în contextul epidemiilor repetate de holeră din Europa, eficacitatea carantinei maritime şi a cordoanelor sanitare a ajuns să fie contestată chiar de oamenii de știință şi de funcţionarii sanitari, singurele locuri unde aceste mijloace au fost eficace împotriva holerei fiind insulele relativ mici, un exemplu în acest sens fiind Sardinia, care a reușit să scape complet de epidemia de holeră din Italia din 1835-1836, prin prevenirea sub pază armată a debarcării oricăror pasageri sau încărcături pe coastele insulei. ${ }^{36}$

34 E. Tognotti, op. cit., p. 255.

35 Ibidem, p. 256.

36 Ibidem; a se vedea şi N. Howard-Jones, The Scientific Backround of the International Sanitary Conferences 1851-1938, Geneva, World Health Organization, 1975, disponibil la https://apps.who.int/iris/bitstream/handle/10665/62873/14549 eng.pdf? sequence=1\&isAllowed=y, pp. 12-13, consultat la 26.10.2020. 
Similar cu situația pandemiilor contemporane, carantina a fost contestată în secolul al XIX-lea de cei care nu credeau în contagiozitatea holerei sau care deplângeau restricționarea comerțului sau a liberei circulații a călătorilor din cauza cordoanelor sanitare și a controalelor de la frontiere, însoțite frecvent de măsuri de fumigare a mărfurilor și de dezinfectare a hainelor. ${ }^{37}$ Chiar dacă existau dubii asupra eficacității carantinei, autoritățile au fost multă vreme refractare la ideea de a renunța la această metodă tradițională, care avea și un efect psihologic asupra populației. $3^{8}$

Criticile aduse carantinei sunt numeroase, ea fiind un instrument „bont”, care afectează mult mai multe persoane decât cele care vor fi efectiv infectate, putând fi eficientă epidemiologic dar lezând din punct de vedere social, economic şi psihologic pe cei neinfectați. ${ }^{39}$ Din punct de vedere istoric, carantina nu avea inițial nicio bază științifică, apărând din cauza incertitudinii și ignoranței privind modalitatea de transmitere a bolilor sau perioada de incubație, chiar durata sa tradițională de 40 de zile având legătură mai degrabă cu concepte religioase sau filosofice legate de boală, în condițiile în care astăzi știm că perioada de incubație a ciumei bubonice este între două şi cel mult zece zile, iar a formei pulmonare a bolii este de numai una sau două zile, astfel că înțelesul tradițional al carantinei este în realitate un amestec nedefinit al carantinei propriu-zise a persoanelor suspecte de boală cu izolarea bolnavilor confirmați.40

Totuși, concluzia experienței istorice privind carantina, confirmată și de ultima pandemie de COVID-19, este că aceasta este o măsură agresivă de

37 E. Tognotti, op. cit., p. 256; N. Howard-Jones, op. cit., pp. 12-16.

${ }^{38}$ E. Tognotti, op. cit., p. 256.

39 M.A. Rothstein, op. cit., pp. 232-233.

${ }^{40}$ Ibidem, p. 233. 
intervenţie în sănătatea publică, ce ar trebui utilizată cu predilecţie la nivel local și, chiar și atunci când este eficientă în privința bolii, afectează libertățile civile, activitatea economică și coeziunea socială, fiind susceptibilă de utilizare abuzivă de către regimurile autoritare..$^{41}$

Din punct de vedere etic, adaptând principiile generale ale intervențiilor de sănătate publică, dintre care carantina este cea mai intruzivă, s-a afirmat că, pentru a se lua această măsură, într-o societate democratică contemporană, ar trebui avute în vedere următoarele criterii: necesitatea, eficacitatea și rațiunea științifică; proporționalitatea și minima încălcare a drepturilor; oferirea de sprijin umanitar celor afectați; justificarea publică a luării măsurii. ${ }^{2}$ În lipsa acestora, carantina poate fi ineficientă, poate cauza revolte ale celor afectați și un dezastru umanitar. 43

\section{B. Cordonul sanitar}

O variantă a carantinei este așa-zisul „cordon sanitar”, care înseamnă restricționarea mișcării populației în sau dintr-o anumită zonă geografică pentru a preveni răspândirea unei boli, fiind practic o carantină „geografică” sau „perimetrală”.44

Termenul a apărut prima oară în 1821, când ducele de Richelieu a utilizat soldații la frontiera dintre Spania și Franța pentru a încerca să prevină transmiterea febrei galbene în Franța, dar măsura în sine este mult mai veche,

${ }^{41}$ Ibidem, pp. 233-236.

42 Ibidem, pp. 250-273.

43 În acest sens a se vedea exemplul negativ al carantinei zonale (cordon sanitar) pentru Ebola dintr-un cartier al capitalei Liberiei, Monrovia, din august 2014, evocat de M.A. Rothstein, op. cit., pp. 273-278 .

44 M.A. Rothstein, op. cit., pp. 232, 235; L.O. Gostin, op. cit., p. 436.

\section{9}


restricționarea geografică a circulației persoanelor pe motive de boală contagioasă apărând de numeroase ori și în secolele anterioare. Astfel, conducătorul oraşului-stat Milano în timpul epidemiei de ciumă din 13981400, Gian Galeazzo Visconti, a instituit un astfel de cordon sanitar avant la lettre, oprind la podurile și porturile de pe râul Adda călătorii din oraşe unde apăruse epidemia să intre în Milano, creând în 1400 rute alternative pentru pelerinii către Roma, care ocoleau orașul. 45 .

Cordonul sanitar avant la lettre, privit ca și componentă a carantinei în înțelesul său larg, medieval, a fost frecvent folosit pentru restricționarea mișcărilor defavorizaților sociali, care erau priviți în orașele-state italiene din secolul al XV-lea, la fel ca în vremea ciumei lui Iustinian din secolul al VI-lea, ca răspunzători de epidemia de ciumă și de răspândirea acesteia: cerșetori, prostituate, sărăcimea bolnavă, pe lângă scopul declarat sanitar insinuânduse ideea controlului stabilității sociale prin limitarea circulației unei subclase sociale anarhice și imprevizibile. ${ }^{46}$.

Autori prestigioşi din domeniul dreptului sănătății publice opinau în deceniul trecut că această măsură a cordonului sanitar are numai o relevanță istorică datorită ineficienței sale, intruziunii asupra libertăţii personale şi a costurilor sociale, privând un segment larg al populației de libertate chiar dacă mulți dintre cei vizați nu prezintă în realitate un risc epidemiologic, aglomerarea indivizilor sănătoși cu cei bolnavi ducând la răspândirea bolii și afectând în general în mod disproporțional pe cei săraci. 47

45 D. Porter, op. cit., p. 34.

${ }^{46}$ Ibidem, pp. 36-37.

47 L.O. Gostin, op. cit., p. 436. 


\section{Izolarea bolnavilor}

Pe lângă precedentele din Vechiul testament, care vorbeau de excluderea bolnavilor cu potențial contagios din societatea israelită, a doua pandemie devastatoare de ciumă care a debutat în secolul al XIV-lea a generat şi ea astfel de politici sistematice de izolare a bolnavilor. În oraşul italian Milano, conducătorul Bernabo Visconti a dispus în 1350 și 1374 ca toți bolnavii de ciumă şi cei care i-au îngrijit să fie trimiși în case special amenajate în afara zidurilor oraşului.48 Urmașul său, Gian Galeazzo Visconti, a hotărât în timpul epidemiei din 1398-1400 ca toți cei bolnavi să fie trimiși la două spitale pentru ciumă, casele lor să fie închise și cei apropiați trimiși în afara oraşului în carantină la mănăstiri, refuzând ideea consiliului orăşenesc de a-i ține pur şi simplu pe bolnavi în casele lor, urmând a fi separați și îngrijiți în spitale. 49

Spitalele pentru bolnavii de ciumă, la fel ca spitalele medievale în general, fuseseră concepute în primul rând ca instituții sociale pentru găzduirea celor săraci, care nu se putuseră refugia din oraşe în fața ciumei şi erau văzuți ca principalele victime ale bolii. Un astfel de spital construit la Florența a ajuns însă să fie folosit în timpul epidemiei din 1497 ca loc de izolare al celor bolnavi (lazaret).50 Lazaretele sau locurile de izolare instituționalizată a celor bolnavi sau suspecți de ciumă au apărut în secolul al XIV-lea în orașele-state italiene sau în coloniile acestora, continuând tradiția

\footnotetext{
${ }^{48}$ D. Porter, op. cit., p. 34 .

49 Ibidem.

$5^{\circ}$ Ibidem, pp. 35-36.
} 
leprozeriilor, care funcționaseră dintotdeauna în afara orașelor pentru izolarea celor afectați de boala lui Hansen (lepră) de societate. ${ }^{51}$

\section{Distanțarea socială}

Deși la începutul secolului al XX-lea părea că bătălia împotriva bolilor contagioase este pe cale să fie câsștigată, carantina și măsurile derivate părând desuete, pandemia de gripă spaniolă din 1918-1919 a adus noi provocări în fața cărora s-a încercat în lumea occidentală luarea unor măsuri ce astăzi, în anul 2020, ne par dureros de familiare: închiderea școlilor, bisericilor, teatrelor, suspendarea adunărilor publice, anularea întâlnirilor publice din campusurile universitare, suspendarea spovedaniilor și a ceremonialurilor funerare, distanțarea socială și măsuri de igienă respiratorie..$^{2}$ Toate aceste măsuri, inclusiv carantina, sunt cuprinse în termenul-umbrelă contemporan de „distanțare socială” (social distancing), care a apărut cu mult înaintea pandemiei din anul 2020, fiind consacrat în literatura de specialitate cu mai bine de un deceniu înainte. 53

Chiar dacă aceste măsuri de distanțare socială par a aparține contemporaneității, istoricii sănătății publice arată că, încă din secolul al XVII-lea, în orașele-state italiene, atunci când comitetele permanente de sănătate publică au crescut în autoritate şi prestigiu, acestea impuneau, pe

${ }^{51}$ M. Lindemann, Medicine and Society in Early Modern Europe, Cambridge University Press, Cambridge, 1999, p. 123; A. Leca, A. Lunel, S. Sanchez, Histoire du Droit de la Santé, Les Études Hospitalières Édition, Bordeaux, 2014, pp. 85-86; K. Park, Medicine and Society in Medieval Europe, 50o-150o, pp. 86-87 in A. Wear (editor), Medicine in Society - Historical Essays, Cambridge University Press, Cambridge, 1992.

52 E. Tognotti, op. cit., p. 257; M.A. Rothstein, op. cit., p. 234.

53 A se vedea în acest sens R.J. Glass, L.M. Glass, W.E. Beyeler, H.J. Min, Targeted Social Distancing Design for Pandemic Influenza, Emerging Infectious Diseases, vol. 12, nr. 11/2006, pp. 1671-1681. 
baza experienței practice, închiderea școlilor, interzicerea festivalurilor, adunărilor religioase și a altor adunări publice în vreme de epidemie, în pofida opoziției vehemente a clerului. 54

Prima pandemie a secolului al XXI-lea, cea de SARS din 2002-2003, a arătat că metodele tradiționale de intervenție non-medicală, vechi de secole, cum sunt carantina, izolarea bolnavilor, supravegherea călătorilor, trasarea contactelor, interzicerea adunărilor publice, recomandările de a crește igiena personală și utilizarea mijloacelor de protecție individuală, au fost eficiente în suprimarea pandemiei în câteva luni de la declararea sa ca atare. ${ }^{55}$ Această boală a arătat însă şi vulnerabilitatea intrinsecă a societăților contemporane, bazate pe contacte sociale extinse şi transfrontaliere, în faţa unei boli noi cu transmitere respiratorie, fără a necesita un vector intermediar, cu o perioadă de incubație asimptomatică de peste o săptămână, cu simptome similare cu ale altor boli, care afectează disproporţionat personalul medical şi se răspândește cu ușurință pe calea transportului aerian..$^{6}$

\section{Cooperarea internațională în domeniul sănătății publice}

Cooperarea internaţională în domeniul măsurilor non-medicale de combatere a epidemiilor a început la mijlocul secolului al XIX-lea, pe fondul pandemiei de holeră, prin intermediul unei serii de Conferințe Sanitare Internaționale (ce au dus după aproape un secol la înființarea Organizației Mondiale a Sănătății), care urmăreau să armonizeze reglementările diferite din statele vremii privind carantina împotriva bolilor exotice, diferențele

\footnotetext{
54 D. Porter, op. cit., pp. 37-38.

55 F. M. Snowden, op. cit., pp. 471-472.

${ }^{5}$ Ibidem, p. 471.
} 
stânjenind în mod considerabil comerțul internațional și circulația pasagerilor. 57

Primele conferințe internaționale în materie au fost un eșec, ignoranța generală privind modul de transmitere al bolilor despre care se discuta (holeră ca pericol acut; ciumă şi febră galbenă ca amenințări tradiționale, care nu fuseseră însă prezente în mod semnificativîn Europa de multă vreme) ducând la dezacorduri pe baza teoriilor diferite despre boală ale reprezentanților fiecărui stat participant 5 .

$\mathrm{O}$ dată ce mecanismele precise de transmitere ale diverselor boli infecțioase au început să fie înțelese de la sfârşitul secolului al XIX-lea, cooperarea internațională a luat avânt, profilaxia ciumei, holerei şi febrei galbene fiind discutate separat, în funcţie de specificul fiecărei boli, iar a 11-a Conferință Sanitară Internațională din 1903 a adoptat o convenție de 184 de articole, care a codificat și înlocuit convențiile anterioare din 1892, 1893, 1894 și 1897, aducând reglementările internaţionale privind carantina în conformitate cu ultimele descoperiri științifice privind ciuma, holera și febra galbenă. 59

\section{Principiile de la Siracusa}

Consiliul Economic și Social al Organizației Naţiunilor Unite a adoptat în 1984 un instrument international cu valoare de soft law, neobligatoriu, elaborat de Institutul Internațional pentru Justiție Penală şi Drepturi ale Omului de la Siracusa. Aceste Principii de la Siracusa arată că restricționarea

\footnotetext{
57 N. Howard-Jones, op. cit., pp. 11.

${ }^{5}$ Ibidem, pp. 12-13.

59 E. Tognotti, op. cit., p. 256; N. Howard-Jones, op. cit., p. 85.
}

\section{4}


drepturilor civile și politice din Pactul Internaţional privind Drepturile Civile și Politice trebuie să îndeplinească standardele de legalitate, necesitate bazată pe dovezi, proporționalitate și gradualitate, sănătatea publică putând fi un temei pentru limitarea anumitor drepturi dacă statul trebuie să ia măsuri destinate prevenirii bolilor sau tratamentului bolnavilor. ${ }^{60}$

Limitarea drepturilor, cum apare în cazul carantinei, trebuie să fie strict necesară, răspunzând unei nevoi publice presante (sănătatea), să urmărească în mod proporțional un scop legitim, cum este prevenirea răspândirii bolilor infecțioase, trebuie să fie conformă legii, să nu fie arbitrară sau discriminatorie, să limiteze doar drepturile aflate sub jurisdicția statului care impune limitarea. ${ }^{61}$

Atunci când este impusă carantina, etica sănătății publice impune ca toate restricțiile să fie susținute temeinic de dovezi științifice, toate informațiile trebuie să fie disponibile publicului, toate măsurile trebuie să fie explicate atât celor ale căror drepturi sunt restricționate cât și publicului larg şi trebuie să fie periodic revăzute şi revizuite. Statul trebuie să se asigure că persoanele infectate nu sunt amenințate sau abuzate, nevoile de bază privind hrana, apa, îngrijirile medicale şi preventive trebuie să le fie acoperite, comunicarea cu cei dragi și cei care le asigură îngrijirea trebuie permisă, limitările privind libertatea trebuie să fie aplicate în mod egal, indiferent de

60 Comisia Națiunilor Unite privind Drepturile Omului, The Siracusa Principles on the Limitation and Derogation Provisions in the International Covenant on Civil and Political Rights, $\quad 28 \quad$ September 1984, E/CN.4/1985/4, disponibile la: https://www.refworld.org/docid/4672bc122.html, consultat la 26 octombrie 2020.

${ }^{61}$ Ibidem.

\section{5}


statutul social, pacienții trebuie să fie compensaţi pentru pierderile materiale suferite, inclusiv salariile pierdute. ${ }^{62}$

\section{Concluzie}

În loc de concluzie a acestui studiu privind aspectele juridice ale sănătăţii publice în contextul istoric al marilor epidemii, nu putem decât să ne aducem aminte de cuvintele cronicarului moldovean Miron Costin, care a trăit și el astfel de vremuri triste, și scria în Predoslovia Letopisețului Țării Moldovei:

„Ce sosiră asupra noastră cumplite acestea vrémi de acmu, de nu stăm de scrisori, ce de griji şi suspinuri. Şi la acestŭ fel de scrisoare gândŭ slobod şi fără valuri trebuiește. Iară noi prăvim cumplite vrémi şi cumpănă mare pământului nostru şi noaă.”

62 A se vedea M.P. Battin, L.P. Francis, J.A. Jacobson, C.B. Smith, The Pacient as Victim and Vector - Ethics and Infectious Disease, Oxford University Press, Oxford - New York, 2009, pp. 313-328. 